\title{
United States Holocaust Museums: Pathos, Possession, Patriotism
}

W itnessing displays of emotion and affect I have not seen at other Holocaust museums or memorials, I explore two US Holocaust museums as a type of theatre, the product as catharsis, and the ruptures between memory, fascism and theatricality. Catharsis, an ancient medical term defined by Aristotle as the 'purgation of fear and pity', may not be the intended outcome of these museums, but its occurrence is disturbingly compatible with the seduction and emotional release identified with Wagner's gesamtkunstwerk. US Holocaust museums seem to challenge the spaces between memory and its direction, between vision and revision, building upon self-consciousness as part of their aesthetic, while commenting upon their own efforts to educate and memorialise. This species of commemoration, and the apparatus of emotion employed by these museums, seems idiosyncratically American.

The United States Holocaust Memorial Museum in Washington DC and Museum of Tolerance in Los Angeles render memory as an experience seeking 
to instruct as well as entertain visitors, who come in droves and leave in tears. Although the two construct the experience of the Shoah differently, that they construct an experience at all is telling. The Israeli museum Yad La Yeled - built in the late 1990s with American funds - uses a similar narrative structure, but does not elicit catharsis. Language is key: although Hebrew as the official language of Jewish resettlement of Palestine predates the horrors of Nazi Europe, prevalence of both spoken Hebrew and contemporary waves of immigration are a direct result of the Shoah and Jews' global realization of the need for permanent refuge. US Holocaust museums necessarily translate the majority of World War II documents, often placing English translations alongside German, Polish, Russian, French and Hebrew originals. This act of translation is, however, cultural as well as linguistic: rendering the meaning Jude verboten as 'No Jews allowed', for instance, the museum contextualises appearance of that phrase on official German placards and propaganda in the early 1930s, and identifies the violence associated with the language. ${ }^{1}$ In German museums this is unnecessary, as the language is understood to signify a process of elimination, not merely exclusion. As manufacture of a Judenrein state was nearly complete in Germany and Poland, it is necessary to describe Jewish life as it was before the Shoah, rather than the pogroms themselves.

In the US, structuring of the Shoah as an historical and cultural event requires not only translation but also transmogrification. But it is not clear why American Holocaust museums depart from the realm of the symbolic employed by Holocaust museums worldwide, seeking instead to construct a substantive experience of the Shoah. The American production concept in many ways resembles the conversion of Auschwitz itself to a place of popular visitation, where scores of visitors descend upon that small museum, walk through a few of the brick buildings, and picnic gaily on the grounds. I will differentiate locales and presentations and describe the finale of museum visitors who, at points of exit (if not before), participate in the museums' foundational subtexts, creating personalized, cathartic displays.

\section{Dislocations}

The Museum of Tolerance is located on a dingy street in a part of the old Jewish district (Fairfax) of massive downtown Los Angeles. In the roughly simulated sparseness of a German camp, captive audiences sit together on stone benches awaiting release from grim stories repeating over loudspeakers. Using highly technical displays of interactive computer banks and Disneyesque conversions of space, the museum directs the play of audience sensation, abstracting the incomprehensible: photography of disquiet and death in obscene volume. As if the drama 
of visual technology were not enough, survivors repeat their tortured narratives in bleak rooms, to eager listeners.

The United States Holocaust Memorial Museum sits in an area apart from the Smithsonian Museums, in the nation's 'memorial core'. ${ }^{2}$ Visitors wander through a glorious brick structure imprinted with scenes and signs of Nazi Europe. Architecture captivates the eye with over-arcing steel girders, walls of glass and capacious emptiness, an effect of cathedral grandeur. A church to dead penitents, this architecture reflects in a literal sense: a portion is made of mirrors. Visitors seeing themselves in the ghastliness are implicated in the space. This is one of the most successful elements incorporated, predating and surpassing curated exhibits.

In both museums the elevated art is death. Dedicated to historicizing the Holocaust, the museums exhibit artefacts of Jewish Europe: clothing, relics, toys and sacred objects, now broken and conscientiously defiled. Pieces of Torah scrolls, 500 years old, cut into decks of Nazi playing cards, drumheads, and shoe soles. Visitors might view these remnants as novelty items, objects with strange black marks: detached from cultural significance, they might even resemble postmodern art, a pastiche of the ancient, modern and mysterious.

Ironically, Third Reich propagandists envisioned these very artefacts as depicting the end of the Jewish people. A 'Jewish museum', created as a memorial to Hitler's 'Final Solution', was the brainchild of Josef Goebbels who, as Minister of Propaganda, anticipated the pending celebration of the utter eradication of world Jewry. ${ }^{3}$ Museum displays of Jewish vestiges are therefore questionable and theoretically unsettling. How is it we have taken up Goebbels' horrible legacy? 'Jewish' museums might have depicted the continuance of Jewish life on hospitable shores. Yet we seem to have come to the same point despite our astonishing survival as a people. Faced with these objects, can visitors comprehend the difference between what they now see and what the Nazis envisioned, between extermination of a people and death of a culture? Between the whiteness of clean museum walls lie bodies tangled in impossible quantities, framed in black and white by the camera's dispassionate eye. Photographs betray their antitheses, reducing the enormity of horror to discrete proportions. Position, juxtaposition and recontextualisation of image and artifact direct the gaze of the present and the play of memory.

In speaking of 'the play of memory', Pierre Nora refers to the flow, even caprice, of memory rather than a consciously constructed, purposefully directed production for audience revelation. But memory is theatrical: it does not produce, but reproduce; memory is itself a work of 
art. In the context of US Holocaust museums, horrific memory becomes a vehicle for enjoyment, and visitors become unwitting voyeurs. What they see is certainly at issue - but what they do is more disturbing. As visitors move about the museum, they travel emotionally from initial curiosity or sympathy to an expression of jouissance. That experience is tantamount to the delight Goebbels expected of good Germans at Nazi 'Jewish museums.' To demonstrate the curious seduction of evil, I closely examine the museums' displays.

\section{THe Museum OF TOleRANCE}

David C. Toole asks, 'Toward what end and in what way should we construct a memory of this finally unimaginable event? ${ }^{4}$ Memory is as prone to interpretation as gender or sexuality; like those other constructions, we are not entirely sure how and why memory works. Photographic documentary of the Shoah in the Museum of Tolerance runs the risk of sentimentality at one end (North American soldiers liberating camps) and perversity at the other (naked shaven people, tattoos, lampshades, soap). Passionless cameras' eyes, frank and flattened displays of picture after horrible picture, reduce human destruction to mass mechanism.

One could expect theatricality to be most prevalent among survivors, but mundane repetition of their stories in the dislocation of small classrooms plays down their pathos. Survivors become curios in the museum, artefacts themselves. There are obviously few survivors, and they dwindle each year; this accounts for Steven Spielberg's commendable contribution to the museum, preservation of survivors' oral histories. But Spielberg is a proponent of digital sight and sound: the museum's third floor is equipped with the latest in interactive hypermedia, the kind of place kids love to play. The website actually bills the museum as 'high-tech, hands on'. Hands on Holocaust? Drop your children off in the afternoon and they will sit mesmerized by the computer screens, pushing buttons to change the scenery, happy as if in a video arcade. But wait: they are in a video arcade. What do they learn from having this power to manipulate imagery on their consoles rejecting parts of history they find boring or too remote, looking for action and reveling in violent death? (And isn't this an old argument from adults concerned about the impact of television on children?) Sadly, because of the remaining survivors' age, Old World accents, and debilitation, they look illadapted to the environment of techno-modernism. Survivor accounts are therefore presented in a sanitised, even censored, fashion, lacking the spin of a complete physical truth.

Many Los Angeles-area schools institute field trips to the Museum of Tolerance, offering it as a new text in American education. But what does it 
teach American students? While the intentions of those who conceptualised, funded and built the museum were honourable, it is problematic, urbanising virtue and dramatising horror. At the outset a conundrum confronts, the quandary identified by Hannah Arendt at Adolph Eichmann's trial: 'This long course in human wickedness had taught us - the lesson of the fearsome, wordand-thought-defying banality of evil' ${ }^{5}$ The museum conflates the Los Angeles Riots (1992), in which some stores were looted and several members of the Los Angeles community died at the hands of African-American protestors; and the Shoah (1933-1945), in which twelve million people perished, among them six million Jews, and uncounted Jews lost all property and connection to family, home or culture. This conflation, treated simply in the museum's naive structure as Floor one and two, demeans both Jewish-American and AfricanAmerican cultures. African-Americans, for whom a national museum was only recently created (after African-American history, Dixieland, jazz and blues museums), must again locate themselves in Jewish philanthropy and protest: black grief is recognized in a Jewish framework, the same ecumenical sensibility with which Jews participated in the NAACP, Anti-Defamation League, ACLU and Rainbow Coalition.

The Museum of Tolerance is not neutrally located; placement in the Fairfax district demonstrates founding and funding by the Jewish community. But although among the first to pay tribute to the African-American trauma, the museum does not reinforce positive aspects of black culture, but features a brief historical crisis: a time when community values broke down, solidarity vanished and African-Americans wreaked havoc upon their own homes, properties and people. Similarly (or conversely) when the Museum of Tolerance opened there was no national Holocaust museum. Jewish Americans thus witnessed to the irretrievable loss of European Jewish culture, and 5,000 years of history, in this newly-built museum - as a detour to a weeklong uprising in Southern California. For non-black Americans the LA Riots represented a sense of betrayal: in the 1990s white Americans believed that relationships between blacks and whites were acceptable, that blacks had accommodated an inferior position (if they recognized the incongruity of American 'equality' at all); many thought that African-Americans had forgiven them, and the enslaved past was a closed chapter. Non-blacks hardly expected the (commonplace) beating of a black man on the white sidewalks of LA to enrage and energize a people, particularly as the beatings were conducted by men entitled to batter, by virtue of vocation. But any similarity between the LA Riots and the Shoah, even in the hopeful SoCal rubric of 'tolerance', is minimal; the symbol of broken shop fronts is insufficient to cocontextualize the events. To suggest that a regional movement of resistance, sparked by a grave singular injustice, be coupled philosophically or physically 
with a continental movement of genocide, planned and legislated to national acclaim, is to neglect the historical particularity of both events.

I do not imply that African American and Jewish American interests or issues are incompatible. A Museum of Persecution could have served both communities, as well as many others. In this (hypothetical) museum, images of black lynchings and cross burnings could be juxtaposed with photographs of death camp hangings, cremation burnings and other horrors. A Museum of Resistance might locate the LA Riots in relationship to other acts of rebellion worldwide, including the underground Resistance of World War II, as when young Hannah Senesz (among other heroic youths of the Yishuv underground in then Palestine) parachuted into Nazi Germany's ignominious torture and death. The Museum of Tolerance demonstrates its claims through the rhetoric of two incongruities, with the sensibility of 'tolerance' rather than 'respect,' 'compassion' or 'comprehension' and the result is LA chic - a belief that simplification is identical to simplicity and good intentions reify abstract constructions.

\section{PLAY WITHIN A PLAY}

Apart from the inherent drama of history's bloody march, revealed by walls of photographs, news placards or propaganda posters and decrees my mother recognizes from her childhood), the Museum of Tolerance is modelled on aesthetic principles of repetition and representation, lifted from Stanislavski, Meyerhold and meta-theatre. Mid-way through the museum, the motif changes from 'objective' documentary to historical fiction, with a selfconscious narrative, fixed characters and play-within-a-play schema. The central play-within-a-play is formed by a series of pictures within pictures built on miniature stages, a voyeurism conscious and cited. Visitors experience a triply or quadruply staged effect, as the narrative requires looking into a museum display where (1a) a story is acted out with (2a) its own slide show (3a) in which visitors ( $1 b)$ join museum figures (2b) in seeing (3b) this show. This inversion of photographic display folds the viewer back into a subject position, simultaneously commenting on the viewer's stance in the audience. Technically the show now includes us, but that is not part of the drama staged: we can envision ourselves as audience, but not (yet) as actors. We are invited to compare ourselves with three 'people' on display and identify as either the principal lecturer (a white man with a British accent) or one of his two associates (a white woman or a second white man, both with US accents).

Made of white plaster and dressed in conventional business attire (painted white), these figures are cast as 'neutral'. But their very 'colourlessness' is unmistakably white-bred, a colonial idea of neutrality complete with the American penchant for European accents, assumed to 
convey greater sophistication and linguistic authority than American tones. In this guise the British male lectures on the more sensitive points to the Americans. Moreover, business suits shift this display suspiciously towards an economy of knowledge as class. Dressed in visible signs of authority, the three prepare for a professional assembly. Given the slide show, suits and officious manner, they seem management types constructing a marketing proposal. Why are they selling the Holocaust?

These white forms direct the enquiry, asking all the right questions. We do little for ourselves as the experience is entirely mediated. These model listeners presumably replicate a predominantly American audience. But a second presumption generated by the British English is that Americans will accept the Shoah as overseas or specifically European history - distant and foreign, not American. Surrogating for visitors, they confer a genealogical exchange. This transmission seems a passing of entitlement, rights to the story; in this simulacrum, as elsewhere in the museum's sub-textual operations, the Holocaust becomes an American possession.

On the first floor of the tour, even the first room, visitors are exposed to 'the facts' of the LA Riots, a tragedy predominantly black and certainly American. By proximity and through interspersed photographs, viewers are invited to compare these riots with genocides in Armenia and Asia.

Californian egalitarianism pervades the building. From there, it is supposedly another step to identifying these tragedies with the Shoah. But that step is also to another storey, another physical remove from the recent, proximate Californian past. That step is another stage, a psychological and conceptual distance from horror on the upper floors. We leave plush carpeting to find cold concrete blocks, Californian representation of the Warsaw Ghetto. By the time we reach the Shoah's penultimate rooms, even those who talk about genocide are white, while the victims are even more comfortably other. In the final room the speaker is unseen, completing the violent translation from self to other, subject to victim.

To bring the spectator to this point requires rapid stage management, a set of comparisons and equivalences. Our role in these mediated tours is to experience cultures the Nazis obliterated. Projected like other images into this space, we tromp fearlessly through room after room in the manner of an occupying army, enjoying a cathartic experience. For some the pleasure ends when they reach the final concrete structure. (Is it colder here? Do we find ourselves standing closer together?) The guards are gone; in this forlorn space, victims' stories are told and retold on overhead television sets, a flourish of technology incongruous with its message. Separated by the placement and convenience of multiple monitors, we do not look at each other and share communal experiences of understanding, but return to private viewing and thoughts, with a medium that encourages isolation and self-gratification. We 
watch, hear the same people dying again and again, a monotony of death almost farcical in repetition.

The Hamburg Institute to Social Research provides a worthy contrast in 'The German Army and Genocide'. This exhibit lays bare the appalling human element through display of photographs taken by 'ordinary' people, noting:
the significance of their amateurishness... Eighty percent of the photos in the exhibit were taken by ordinary soldiers in the German army, and most record actions by the regular army, not the SS, Waffen-SS or the Einsatzgruppen killing squads...The exhibit has catalyzed the cleaning out of some dark recesses of Germany's mental attic. Several dozen people have come to the exhibit bearing family albums containing photos like those in the exhibit - photos of soldiers cutting the beards off Jewish men, photos of bodies hanging from street lamps. These photos are in albums side by side with photos of the soldiers' families' vacations. ${ }^{6}$

The human element encompasses an impulse so inhuman it is a wonder German families were able to admit to their share in the legacy. By displaying these photographs they may reject their forebears' actions. But they cannot control who sees the photographs or how they are viewed. They may thus (unintentionally) participate in a display of personal and communal satisfaction, an exhibition that attracts viewers because they admire actions on display. Bernd Greiner of the Institute admits to the powerful social process this exhibit initiated: 'We, the originators of the exhibit, were expropriated of our product. The public took over'. ${ }^{7}$ German national memory confronts the individual faces of its machine. But the perpetrators are still smiling, and perhaps not only in photographs.

The Museum of Tolerance employs local tour guides to guide public perception: on my first visit the tour guide explained (in an indignant Valley Voice), 'They were trying their best to get rid of the Jews'. This language of reduction is aimed at the museum's perception of the common visitor. Assuring us 'You don't have to know anything about computers', Amber invited us to 'Go to the Memorial Plaza, where you can enjoy yourself!' She urged visitors, exiting a room in pairs, 'Don't tell anybody anything that happens!' so that the enjoyment of the next two into the space would not be curtailed. That visitors are made complicit with a secret in the museum is ironically recalls the secrecies of Nazism. When faced with two closed doors I chose one, whereupon Amber sniffed: 'You've obviously been here before'. (She found it inconceivable 
that I might solve the puzzle without help: visitors are not expected to negotiate the museum.) In one room visitors could change their images by selecting varied vocations that showed up as pictures. Could any endeavour be more symbolic of the pretence and deception of Third Reich politics, in which hired actors delivered public addresses?

In contrast to the room of survivor memoirs, where I saw no emotion on visitors' faces, the majority of guests write lines of passionate and sensual enjoyment in the Museum of Tolerance's farewell register. Viewers are permitted to look at everything available - then unburden themselves before they leave. The instance of the pleasure is revealed by the gush of sentiment in writing, altering the medium yet again. I found journal entries filled with exhilarated comments: 'Jesus Christ - Oy!' 'Very interesting and gruesome very sad.' 'Hazaq me-od (Hebrew for 'really strong'). 'Very educational and an experience of a lifetime'. 'This museum is wonderful'. 'Mindblowing'. 'Cool!' ‘Groovy!' 'I liked it very much'. And 'Damien white 5'11" Fine as Hell, call me any time all day Pgr. \#398-3218' - followed by 'Myron Mathews \#27 DHS 5'9' 164 fine as hell'. Initially disgusted by the use of the museum diary as a teenage dating service, I now appreciate the candour with which Damien and Mathews, 'fine as hell', located themselves in the museum machinery. They refused to be transported, to participate in what Nietzsche might decry as a fascist operation of emotion. Remaining mindful, even to the point of selling themselves, these young men more likely departed the museum intact, not liberated of their feelings. In the context of the museum of Tolerance, where the invited catharsis takes place within the architectural grounds, these two would have failed the museum's mandate but fulfilled my own: instead of discharging their sensations, they carried the message of the museum out, un-purged and residing within.

\section{The United States Holocaust Memorial Museum}

This is a very different museum. Located in Washington DC, Americans' apparent dislike for museums (mentioned in museum commission's internal literature) does not figure. Within a year of opening, the museum was alarmed to announce that it had aged five years, merely as a result of constant traffic in the building. It is common for visitors to exceed the population for which this building is coded, and the museum instructs potential visitors by brochure and web to make a reservation or be ready to be turned away. So ubiquitous are the warnings, I feared I would not be admitted. One may stand on line for hours. The commonly held reason is that the museum is free of charge $-\mathrm{a}$ foolish assertion as 
Smithsonian Museums are free, and the only Smithsonians limiting patronage are those housing special, brief exhibitions (which are still free). The first day I visited the US Holocaust Museum I had no reservation, and although I arrived nearly an hour before it opened to a cold winter morning, more than 30 people had already lined-up outside. There were not - as yet - any groups. By the time I entered, hundreds waited in a line snaking onto the street and around the building to the back, overseen by security guards and museum personnel. That was an ordinary day.

What accounts for the museum's vast popularity with Jews, nonJews, Americans and foreigners? The large edifice of brick lacks any of the beauty of patriotic legacy, like the old Treasury Building up the street. Inside, the building emulates aspects of concentration cellblocks at Auschwitz I, where the architecture recalls a conference venue, a landscaped academy complete with student dorms. One sweeps into travelling exhibits (a separate, free ticket) or the permanent spaces. A small machine automatically issues a 'passport' consisting of a stranger's face, often that of a child, and more akin to travelling documents of the 1940s than current American passports. This dramatic flourish theoretically plays with how governments shape geographies and document human passage within its borders.

The museum intends visitors to travel in the guise of an arbitrarily bestowed foreignness, to be other than we are, specifically, victims of Nazi pogroms. Plainly the wish is for visitors to check their citizenship with their coats, and empathize with the plight of others, even for a few seconds: this exhibit does not, as in the Museum of Tolerance, coerce visitors into an experience of embodiment. But the passport does not permit individuals to supersede emotional boundaries as they enter, see, and contemplate messages of nationhood, nationalism and identity. Visitors are continually reminded of the dialectic between citizenship and ethnicity, or identification and self, with recurrent American patriotic references throughout the building.

Jeshajahu 'Shaike' Weinberg, consultant for the US Holocaust Museum, called his work an 'exercise in visual historiography, a crude method for expression [where] one cannot be subtle'. ${ }^{8}$ Through 'meaningful arrangement of artifacts, photographs, audiovisual displays, and interactive information retrieval facilities', he wished to create an act of storytelling. A Polish born immigrant to then-Palestine, Weinberg was brought to the U.S. Holocaust Museum because of his consultancy with Beth Hatfutsoth. Ironically, he claims he 'slid' into museography after being asked for help by friends. He was then director of the Cameri 
Theatre in Tel Aviv. The theatrical legacy Weinberg might bring to the Holocaust did not go unrecognized - or unchallenged: a possibility his ideas would make the museum too 'Disneylike' were addressed before Weinberg was brought into the group. ${ }^{9}$

Prior to the erection of the museum, Michael Berenbaum delineated the US Holocaust Memorial Council's governing task as a deliberate and self-conscious Americanization of the Holocaust in which the memorial would speak to all Americans regardless of provenance. Unlike that of Yad Vashem in Jerusalem, he notes, the design of an American Holocaust museum must consider a diverse and foreign audience, the Americans themselves. Berenbaum problematises the effort as dangerous:

The American museum... runs the risk of creating a magnet for anti-Semitism if others who perceive themselves, rightly or wrongly, as victims of the Holocaust feel excluded from the memorial and / or sense that their suffering has been trivialized or denied. The museum must grapple with the problem of complicity with the Nazis in the destruction of the Jews by people who were themselves the victims... must also explore the dilemma of the bystander in a way that makes sense of the few successes and many failures of American policy regarding the Holocaust during and following the war. Because the American museum is a government project (appointments to the council are made by the president), the council cannot be fully insulated from the political context in which it operates. ${ }^{10}$

Despite this cautionary tale, Berenbaum admonishes us not to confuse the audience with the content, claiming that the Holocaust 'is only Americanized insofar as it is explained to Americans and related to their history with ramifications for future policy' ${ }^{11}$ This would seem representative of the schizophrenia expressed by the museum, which issues artificial identification with a victim who, embodied in the passport, can be abandoned at any stage. This not only permits but also persuades viewers to confuse themselves with content, while presenting the Holocaust as a foreign evil, and liberation of the camps as an event for which Americans took physical and moral responsibility.

Promotional materials from the museum admit to an effort to 'Americanise' the experience of European Jews, simplifying and 
sanitising a lost culture for ready modern access. Does this 'reinvention' adequately communicate Jewish experience? Or does it satirise, by locating torture and genocide in the context of what one magazine reviewer called 'an American theme park'? ${ }^{12}$

Ruminating on the development of a museum aesthetic, Michael M. Ames writes:
We are now entering an era where formerly dominated and under-represented populations - at least those who survived - are asserting their rights to self-determination and to control of their own histories. Museums will be expected to respond creatively. Will they be able to $?^{13}$

There is no question museums can respond creatively; that they do respond creatively is a dilemma, as museums join the battle for arts funding and audience subscription. The museum operation adopts an aesthetic powerfully similar to Roman theatrical constructs: in this arena they mix the violence of gladiators, the innocence of martyrs, and a pornographic over-abundance once called 'Epicurean'. In this admixture comes a huge dose of catharsis, the 'purgation of fear or pity' found in Greek Tragedy. Like senators vomiting into the theatres' aisles (hence, vomitoria), visitors are enabled to empty themselves in the building, and emerge clean, cleansed, lightened. In the US Holocaust Museum, where messages are more forthrightly solicited from children, spectators relieve themselves of the weight of the image. From the many visitors I have watched writing memoirs at the museums' exits, exhaustedly quenching appetites in the cafeteria, and swinging off down the street, I conclude that instead of feeling educated they feel morally uplifted and publicly entertained.

The Museum of Tolerance and US Holocaust Museum seek to stand as symbols of national earnestness, as preventative pills or plasters. Philip Gourevitch denounces the Holocaust Museum as an 'ideological vaccine for the American body politic'. ${ }^{14}$ The banner of an article on the Museum of Tolerance touts 'A Museum of Hate'. ${ }^{15}$ As in Israeli pioneer museums, where the dialectic of memory and history plays itself out in a museum context', ${ }^{16}$ memory's own dialect, with its disparate voices, seems to offer more than one point of view. But as one moves up the museums' levels to hyper-textuality and high technology, the views remain the same. 


\section{Pedagogy}

Edward Linenthal comments on the difficulty of telling 'the story of the Holocaust' without overly 'softening' its impact:

The museum's mission was to teach people about the Holocaust and bring about civic transformation; yet, since the public had to desire to visit, the museum felt the need to find a balance between the tolerable and the intolerable. $^{17}$

These two museums instruct viewers to believe rather than reject, apparently agreeing that what is being shown is unbelievable. The structure of our 'memory' of Shoah is maintained, in some cases created, by the museums' particular attention to visitors as audiences. This method is unfortunately reproduced by the museum's techniques of education, which consciously build emotional response in visitors, but incompletely theorise the nature of that response. The many 'theatres' in the Museum of Tolerance provide places of relative darkness and repose among the lit atrocities, while playing to the production of catharsis. The United States Holocaust Museum's play of architectural recesses and reflections causes a similar dramatic effect in its viewers, while a space set apart and constructed as a Jewish child's 'story' targets younger audiences and provides a place for them to 'write back' to the (dead) child.

Adorno movingly warns of the dangers of catharsis as sedation and neutralisation, negating individual agency, social and political action, and therefore potential resistance to evil. I feel that the direction of the American Holocaust museums can be instructively compared with the 'conductor' (Wagner himself) Adorno criticises. Like Wagner, the museums 'enforce this collusion' between the audience and the museums' manipulation, meanwhile 'maintaining the appearance of strongly individual opposition' (actually, individuality); the museums, too, 'establish the power of impotence in the realm of aesthetics'. ${ }^{18}$ The museums' similar use of guest albums encourages support rather than resistance, 'incorporating the public in the work as an element of (their) "effect". ${ }^{19}$

These museums offer the completely absorbing aesthetic experience of Wagner's gesamtkunstwerk. In this vein we can read Adorno's critique of the seductive apparatus:

The uncontrollably intensified expressive impulse can barely be contained within the interior, within historical consciousness, and finds release as external gesture. It is this that gives the listener the embarrassing feeling that someone is constantly tugging at his sleeve. The strength 
of the constructivist element is consumed by this exteriorized, quasi-physical intensity. ${ }^{20}$

The productively externalised gesture is the audience's written comments, the constant 'tug' repetition of a message that, like Wagner's leitmotif, unconsciously fix sensory and intellectual associations. Exhibit rhythms calculate an imagined audience's responses - 'murmurings of the people, applause, the triumph of self-confirmation, or waves of enthusiasm ${ }^{21}$ - yet heavily reiterate their motif as if for the first (or last) time. The manipulation so seductive it seems only right.

By reviewing the way these and other tragic images are assembled in popular culture, and our place in them, we are closer to knowing how American Holocaust museums propose to educate while succeeding to titillate. Perhaps American Holocaust museums are foremost American and only secondarily Jewish projects. One could hardly find a more fundamentally and unarguably 'American' project than the Buffalo Bill Historical Centre in Cody, Wyoming, which displays a similar ethos. Jane Tompkins delineates the museum's purpose:

It is a kind of charnel house that houses images of living things that have passed away but whose life force still lingers around their remains and so passes itself on to us. We go and look... as if by standing there we could absorb into ourselves some of the energy that flowed once through the bodies of the live things represented. A museum... caters to the urge to absorb the life of another into one's own life... museums are a form of cannibalism made safe for polite society. ${ }^{22}$

A museum's mandate is to provide an observable past, elucidated by those who know more about it than those who visit. Museums now equate looking with entertainment, and provide information about with an experience of the past. A part of the discomfort scholars may recognise in American Holocaust museums is delivered by the museums' realisation of enshrinement. There is a sense that the Nazi period is enshrined in Jews' collective memory, as an end to Jewish history, and that museums serve as shrines, enclosing and concluding Jewish culture. The conclusion of Jewish culture in the museums' enshrining is not a conscious suggestion but a repeating aberration. Universally accepted as a device for art as well as documentation, the photograph is already a dramatic structure. Housing these dramas, even without the interference and interaction of other structures the museum becomes a drama within a drama, the photographic mount. Because of their mandates to serve 
art and truth (or art as truth), museums function as legitimate purveyors of power fantasies by radically reconstructing photographic documentary as theatre. 'Public events are conveyances... [which] mediate persons into collective abstractions. ${ }^{23}$

In 1955, Ionesco wrote:

The theatre, like all art, must serve no utilitarian purpose; the theatre is not engagement but dégagement; none the less, this 'disengagement', this alienation, this forgetfulness of self, this violent separation from the utilitarian world, is a usefulness without which we cannot live... ${ }^{24}$

To forget and purge the self is not to enact public memory but to wallow in selfhood, forgetting the other.

\section{POLITICS OF PLACE}

The creation of Jews as vulnerable Others requiring masculine protection, configured in the US as the might of the American military, is yet another way of reducing Jews to the status of victims, maintaining a separateness that may lead to such pogroms. Both these museums are interactive texts, encouraging students to 'feel their way'; yet because museums function as elite collections with entitlement to aesthetic production, viewers take away experiences of the Shoah as just that - aesthetic. The seduction of feeling does not invite change so much as catharsis, an emotional and physical release. This response unfortunately replicates the very techniques used by Goebbels for the glorification of Hitler. In providing visitors with the opportunity to 'feel' the Holocaust, the museums move beyond the bounds of educational or documentary fora; they participate in a strange kind of venture - the reduction of the past to the experience of the present. Christian Metz explains the difference:

The goal of the reconstruction... is not to reproduce reality; the reconstruction is not a reproduction, it does not attempt to imitate the concrete aspect of an original object; it is... a simulation, a product of techne... the result of a manipulation. ${ }^{25}$

Where is the judiciousness in simulating the Shoah? The purpose of simulation in learning to operate Stealth fighters is evident: Air Force pilots require special learning, an education too costly and harmful to deliver in any but virtual combat. Simulation protects potential pilots, 
drivers, mechanics and others from the danger of the real. If simulation succeeds in training individuals to perform specific, vital and complex tasks, might the techne of American Holocaust museums teach the public to perform the work of the Holocaust?

Museum articulations of history by definition architect a point of view, literally a point from which to view any number or type of data. Tamar Katriel states that museum sites are

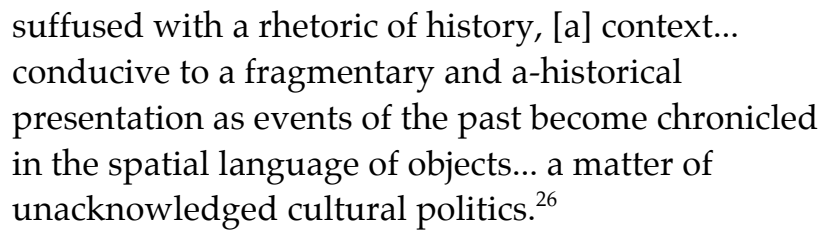

Museums are prone to rationalizing the historical liberties they take, such as the building of exhibits with agricultural tools anachronistically placed where they 'might' have been - but historically were not. Museum curators, administrators and scholars knowingly manipulate public vision. Museums are institutional sites and as such bear institutional burdens: the need for political conversion of transitory souls (visitors) ensures economic salvation of the museum's body. Even historical museums do not present but represent historical events, dialoguing with rather than depicting time.

Describing the façade of the Apartheid Museum in Johannesburg, Georgi Verbeeck notes that museum investors wanted the new Apartheid Museum to resemble the Holocaust Museum in Washington DC; but the museum unselfconsciously built a 'symbol of the ironic character of the post-apartheid era':

It is in the middle of an enormous car park with an old-fashioned roller coaster in the background. The contrast cannot be greater: on one side a row of cars parked in the shade of palm trees and on the other a building surrounded by an indigenous African landscape... ${ }^{27}$

Within, the Holocaust Museum appears to be invoked in such motifs as a wall of mirrors and passport-type entrance. In the Apartheid Museum, viewers are invited to choose a path through the museum that is either 'non white' or 'white':

The museum's message is linear; the simple principal of racial segregation itself undoubtedly 
leads to chaos, misery and destruction. The outside of the building (straight lines mostly under an aqua blue African sky) recalls images of terror and repression. Claustrophobic feelings overwhelm... Curious one wanders through a wall of mirrors in which one cannot be sure who is watching whom. But it is only when one is inside that the labyrinth really begins... ${ }^{28}$

Verbeeck describes customary artifacts of a museum that contribute to the archive. There are also signs, 'execution poles', televised segments and an armoured car. Comparisons between the Holocaust Museum and Apartheid Museums are thus strongly pursued despite the museum's incongruous exterior.

The aesthetic and educative principles of the Apartheid Museum also appear to have been modeled along the lines of the Holocaust Museum. Through such architectural motifs as the mirrors, 'the Apartheid Museum presents itself as a mirror for the new nation. ${ }^{29}$ And social historian Phillip Bonner

makes sure that the past of apartheid is not reduced to a few dramatic moments and highlights and that the forgotten layers of the population and the anonymous masses will also be represented... All forms of multimedia are prominently present. For all of these reasons, the museum could become a major tourist attraction in the growing network of museums and monuments devoted to South Africa's recent history. ${ }^{30}$

But where the Apartheid Museum's linearity and 'mostly straight lines' tell the story of racial divisions in South Africa, the Holocaust Museum's 'bridges' - as reported by architectural critic Adrian Dannatt - move viewers to new understandings of fascism and discrimination:

It is also only from these bridges that the full crookedness and distorted proportions of the main hall below can be understood... a distorted, ruptured structure, just as the classical foundations of fascist society seen from the overview of history appear as barbarism, insanity, chaos. ${ }^{31}$

No longer storehouses of curios, museums are now strategic arsenals. As Ellen Futter says of the New York Museum of Natural History, the museum 
can 'help create a more effectively functioning democracy, and thus a public that has a better sense of connectedness to each other, to cultures all over the world, to other species'. ${ }^{32}$ At the same time, Futter foresees the Museum (at least, 'her' museum) as one 'without walls'. ${ }^{33}$ Her 'virtual museum' may provide a location from rather than in which to see the world, yet visitors must first reorder a tradition of looking at museums as mantles for cultural trophies, and see themselves as part of the museum. In this virtual space visitors may find they belong to, rather than in, the museum, as a relic of past responses.

\section{American Patriotism}

As private property, memory may be reconstructed at will. Public memory is a contested space of shared myths. Stored in a mosaic of sensory language, all memory is subject to a ratio of displacement over time. Contents shift while moving - or are lost in storage. What remain are monuments to someone's view of that history, architectural moments that invariably deface (or replace) the mnemonic landscape of some while justifying the past oppressions of others. Even language becomes complicit in the work of historical revisionism, leeching memory of its true murderer.

The museum corrals our viewing, impressing us with its perception of 'tolerance' and order - an order and aesthetic specifically American. US Holocaust museums shape public perceptions and memory of World War II events by positioning American patriotic interests at the forefront of the exhibits. They therefore background issues of ethnicity, religion, politics, victimisation and suffering, other patriotisms, and even German nationalism. Displays tell a carefully selected portion of the story, edited for its 'American' voice - that is, highlighting the characterisations of victims most closely aligned with Americans' own, and emphasising (one might say exaggerating) US heroism. In this configuration, American troops become saviours, the first to tramp or roll in and liberate the camps. Sometimes American troops are the only Allies visibly active in the war.

Further, the voice of American pluralities is under-erased by the museums' depictions: the saviors of World War II Europe are not only American but also white. Yet, an African-American platoon liberated a Polish camp. Liberation of Dachau by Japanese-Americans of the 442nd army battalion is another suppressed story. For political purposes, American heroes were uncomplicatedly Anglo, white, Christian and enfranchised. They would not return to interment camps on the West Coast, or segregated water fountains in the South, would not wash bloody crosses or swastikas from their front doors. There are likely other reasons for the representation of the liberators as white Everymen. But one dramatic element is readily visible in 
the portrayal of Americans marching in, as they did to Stalag Luft III. A Prisoner-of-War, my father remembers the liberators as healthy, robust, upstanding men. General Patton, who led this liberation, stood up in a tank, a dashing figure. The prisoners had been starved, but not brutalized, flayed, medically dismembered or gassed: my father's jaundiced, emaciated body would never compare with the aged and wizened stick-figured victims of the concentration camps.

The image of healthy white Americans could not be further from the reality of those almost unbelievable visions, the tattooed, hollowed and crippled men and women standing at the barbed wire, draped in blankets thicker than their own flesh. The difference between saviour and the saved adds dramatic effect to an already pathetic vision. I suggest that the appearance of Jews - like Roman and Sinti, representative of a dark, arcane other - is to a great extent partly responsible for the whitening of the liberators: problem people can only be saved - or solved - by an unproblematic hero. Thus was born the myth of the white American liberator.

US Holocaust museums share the difficult burden of being houses for dead and living cultures: mourning the loss of European Jewry, celebrating the birth of Israeli Jewry, and acknowledging the survival of Jews in the US. They demonstrate the absence of Jewish life around the world while projecting viewers into the tragic preoccupations of contemporary Jewry in 'newer' worlds. Dr Hadassah Rosensaft, Auschwitz survivor and founding chairman of the International Network of Children of Jewish Holocaust Survivors, warned the US Holocaust commission: 'Anyone who casts aspersions [in the museum exhibitions] on their [Holocaust victims'] memory somehow participates retroactively in their murder. ${ }^{34}$

It requires active denial to imagine modern Jewry without contemplating the Shoah as both effect and cause. Jews' collective memory elides past trauma with present experience, meaning that the work of mourning cannot be concluded. Jewish events, including or especially those in the 'past' are a felt history; past pogroms reflect future misery, a life in which one cannot cease one's vigilance. For a people whose collective memory is central to its identity, the Shoah is a knife to the bloodline, and those who survived are also those who did not.

US Holocaust museums have a special mandate to establish a connection between people in the US and European Jewry. This is complicated by a certain guilty complicity of some Americans, of governmental rejection of the Jews' plight during the years of Hitler's rise and reign, and the long period before the US entered the war. The museums also bear proxemic burdens of distance and foreignness, of being erected in a space with no direct relationship to the events (unlike memorial museums in Auschwitz or Berlin). These traumatic 
transplantations must work to bring the horrors 'home' in a place that is not home to them. The museums' references are alien.

In contrast, the District Six Museum of Cape Town commemorates an event of historical significance and trauma in Cape Town and, while the museum is not located on the grounds of District Six, but in the city centre, District Six not far away. Museum visitors can take a Red Bus to the district; visitors curious about the large green and undeveloped swath of land in an otherwise teeming cityscape can travel two kilometres to the museum. The two sites are in such proximity that they speak to each other.

This is not true of Holocaust museums - at least in the US, Australia, New Zealand, South Africa or Israel - where the visitor encounters different politics of location. Apart from manifold curatorial and testimonial decisions, including those of theatrical presentation and 'message' bearing, are obvious geographical choices. Then again, nothing has proved simple at Auschwitz, where spaces are contested by various religious groups. ${ }^{35} \mathrm{~A}$ clear if superficial dichotomy exists between museums in Poland, Germany or the Netherlands, where Jewish communities thrived prior to the Shoah, and, for instance, Australia, the US and South Africa. Superficial because there are complicated histories in every country, despite their physical remove from Holocaust geography, and each owns (or disowns) a shameful and complicit past of fascism, silence, eugenics, or outright Nazism. So while the ashes of twentieth-century Jewry literally swirl in eddies of postapocalyptic Europe, Jewish remains haunt the shores of every nation. If Jews were not actually rejected by these countries while fleeing desperately from Hiter's ovens, then almost every nation is complicit in having failed to act decisively, or expeditiously, of not having done enough. (Compare more recent genocides in Bosnia, Rwicanda and Darfur.)

'Jewish museums' strive to shine a glaring light upon the Nazi reign over Jewish life and culture. But by virtue of the methods US Holocaust museums employ, they may succeed instead in problematising the apparatus of display and seduction. The museums' moral ethos enforces a view (or review) of the Shoah, suggesting that Jewish victimization is a European phenomenon while Jewish liberation is an American one. Through gesamtkunstwerk of architectural intellect, the museums physically mythologize American participation, marketing the genocide as an American success story. Produced as catharsis centres, these museums mount a seductive play on audience sensibilities in which the public is guided to a singular, self-consciously upright, finale. Sadly, 
despite their carefully correct historical constructions, United States Holocaust museums suggest that to re-enact the evil is to act it once again.

\section{ENDNOTES}

${ }^{1}$ Rob Baum, 'Deconstruction of Jewish Identity in the Third Reich: Nazisprache und Geopolitik', National Identities, no 2, June 2006, pp95-112.

${ }^{2}$ Edward T. Linenthal, Preserving Memory: The Struggle to Create America's Holocaust Museum, Penguin Books, New York, 1995, p59.

${ }^{3}$ Goebbels conceived and established the Jewish Museum in Berlin as early as 1933. As James E. Young has asked of Daniel Libeskind's Jewish Museum in Berlin: 'How does a city 'house' the memory of a people no longer at 'home' there?' See Rob Baum, 'Visual Culture and the Holocaust', Journal of Genocide Research, vol 8, no 3, 2006, p366.

${ }^{4}$ David C. Toole, 'Witnesses and Voyeurs: The Perils of Remembrance in Orbit of Darkness and Schindler's List', Soundings: An Interdisciplinary Journal, vol 77, nos 3-4, 1994, p285.

${ }^{5}$ Hannah Arendt, Eichmann in Jerusalem: A Report on the Banality of Evil, Viking Press, New York, 1963, p231.

6 George Will, 'Old photos bring catharsis,' Opinion, El Paso Times, 22 December 1999, px.

7 ibid.

${ }^{8}$ Linenthal, p142.

${ }^{9}$ op cit, p143.

${ }^{10}$ Michael Berenbaum (ed), A Mosaic of Victims: Non-Jews Persecuted and Murdered by the Nazis, New York University Press, New York, 1990, p23.

${ }^{11}$ Op cit, p24.

${ }^{12}$ Philip Gourevitch, 'Behold now behemoth: The Holocaust Memorial Museum America's Newest Theme Park', Harpers Magazine, July 1993, pp55-62.

${ }^{13}$ Michael M. Ames, Cannibal Tours and Glass Boxes: The Anthropology of Museums, Vancouver: University of British Columbia Press, Vancouver, 1992, p13.

${ }^{14}$ Gourevitch, p58.

${ }^{15}$ James Willwerth, 'A Museum of Hate', Time Magazine, 15 Feb 1993, pp54-5.

${ }^{16}$ Tamar Katriel, 'Israeli pioneering museums, sites of memory', Quarterly Journal of Speech, vol 80 , no 1,1994 , p8

${ }^{17}$ Linenthal, p198.

18 Theodor Adorno, In search of Wagner, trans. Rodney Livingstone, Verso, London, 1991, p30.

${ }^{19}$ op cit, p31.

${ }^{20}$ op cit, p35.

21 ibid.

${ }^{22}$ Jane Tompkins, 'At the Buffalo Bill Museum: June 1988', South Atlantic Quarterly, vol 8, no 3, 1988, p533.

${ }^{23}$ Don Handelman in David Cheney, Fictions of Collective Life: public drama in late modern culture, Routledge, New York, 1993, p15.

${ }^{24}$ Eugene Ionesco, 'Theatre et anti-Theatre', Cahiers des Saisons, no 2, October 1955, pp149-51.

${ }^{25}$ Christian Metz, Film Language: The Semiotics of Cinema, trans. Michael Taylor, University of Chicago Press, Chicago, 1974, p36.

${ }^{26}$ Katriel, p6.

${ }^{27}$ Georgi Verbeeck, "'Structure of Memory": Apartheid in the museum', in Hans Erik Stolten (ed), History making and present day politics: the meaning of collective memory in South Africa, Nordiska Afrikainstitutet, Uppsala, 2007, pp217-18.

${ }^{28}$ op cit, 220 .

${ }^{29}$ ibid.

${ }^{30}$ op cit, p221.

${ }^{31}$ Linenthal, pp168-69.

32 James Traub, 'Shake Them Bones', The New Yorker, 13 March 1995, p59.

${ }^{33}$ ibid.

${ }^{34}$ Linenthal, p110.

${ }^{35}$ Johnathan Webber, 'Memory, Religion, and Conflict at Auschwitz: A Manifesto', Religion, Violence, Memory, and Place, Oren Baruch Stier and J.Shawn Landres (eds), Indiana University Press, Bloomington, 2006, pp51-73. 